\title{
ACETYLCHOLINESTERASE INHIBITORY ACTIVITY OF GALANTHUS GRACILIS AND G. XVALENTINEI NOTHOSUBSP. SUBPLICATUS
}

\author{
(C) Unver Somer N., Sarıkaya B., Onur M. A., Kaya G. I.
}

Department of Pharmacognosy, Faculty of Pharmacy, Ege University, Bornova-Izmir, 35100, Turkey

Alzheimer's disease (AD) is one of the most common cause of dementia in the elderly people. It is known to affect about 36 million people around the world. Acetylcholinesterase (AChE) inhibitors are major drugs for the symptomatic treatment of AD. Natural products constitute an important source for AChE inhibitors. For example galanthamine, an Amaryllidaceae alkaloid is used in the treatment of mild to moderate AD. Moreover, some Amaryllidaceae alkaloids have been found to exhibit similar or more potent AChE inhibitory activity when compared to galanthamine $(1,2)$. Therefore, Amaryllidaceae family is considered a major source to find better AChE inhibitors. Among the Amaryllidaceae genera found in Turkey, the genus Galanthus is represented by 14 taxa and one hybrid (3). In the present study, the AChE inhibitory potentials of Galanthus gracilis Čelak. and a naturally occuring Galanthus hybrid, G. xvalentinei (J. Allen) Beck nothosubsp. subplicatus (N. Zeybek) A. P. Davis were determined. A microplate assay modified from in vitro Ellman's method (4) is used to evaluate the AChE inhibitory activity of the alkaloidal extracts prepared from the bulbs and aerial parts of the above-mentioned plants. The final concentrations of the extracts in the assay ranged between $0.25-150 \mu \mathrm{g} / \mathrm{ml}$.
The enzyme inhibitory activity was calculated as a percentage compared to blank. $\mathrm{IC}_{50}$ values were evaluated by software package GraphPad Prism V3.0 (GraphPad Software, San Diego, CA). All of the extracts prepared from $G$. gracilis (bulbs: $I_{50}=11.82 \mu \mathrm{g} / \mathrm{ml}$, aerial parts: $25.5 \mu \mathrm{g} / \mathrm{ml}$ ) and $\mathrm{G}$. xvalentinei nothosubsp. subplicatus (bulbs: $\mathrm{IC}_{50}=21.31 \mu \mathrm{g} / \mathrm{ml}$, aerial parts: $16.32 \mu \mathrm{g} / \mathrm{ml}$ ) showed remarkable AChE inhibitory activity. Galanthamine was used as a positive control $\left(\mathrm{IC}_{50}=0.043 \mu \mathrm{g} / \mathrm{ml}\right)$.

References: (1) Williams, P., Sorribas, A., Howes, M.-JR., (2011) Nat. Prod. Rep. 28 (1): 48-77. (2) Houghton, P. J., Ren, Y., Howes, M.-J., (2006) Nat. Prod. Rep. 23: 181-199. (3) Davis, A. P., (2006). The genus Galanthus-snowdrops in the wild, in: Bishop, M., Davis, A.P., Grimshaw, J. (Eds), Snowdrops, A Monograph of Cultivated Galanthus, Griffin Press Publishing Ltd, Cheltenham, pp 9-63. (4) L pez, S., Bastida, J., Viladomat, F., Codina, C., (2002). Life Sci. 71: 25212529.

Acknowledgements: This study was financially supported by Ege University Research Fund (09/ECZ/021).

\section{SCAVENGING EFFECTS OF HYDROLISATES OBTAINED FROM THE SEA URCHINS COELOMIC FLUID}

\author{
(C) Urakova I. N., Pozharitskaya O. N., Makarov V. G. \\ St-Petersburg Institute of Pharmacy, 47/5, Piskarevsky prosp., 195067, St-Petersburg, Russia
}

Sea urchins possess an innate immune system and are regarded as a potential source of bioactive substances due to their coelomic fluid (CF). Coelomocytes constitute the defence system, which is capable of chemotaxis, phagocytosis, and production of cytotoxic metabolites. Bioactive substances from marine source may be produced by enzymatic hydrolysis of marine organisms and isolated tissues. Peptides and amino acids of the hydrolisates may exhibit significant antioxidant properties (1). Coelomic fluid from the fresh green sea urchins Strongylocentrotus droebachiensis were collected and hydrolyzed immediately during 1.5 and 3 hours at $50^{\circ} \mathrm{C}$. The enzymes used were: Alcalase $2.5 \mathrm{~L}(\mathrm{~A})$, Flavourzyme $1000 \mathrm{~L}(\mathrm{~F})$ (Novozymes, Denmark) and Protex 6L (P6L) (Genen- cor International, Netherlands). Process of hydrolysis was stopped by heating in boiling water for $10 \mathrm{~min}$ to inactivate proteases. The coelomic fluid hydrolysates $(\mathrm{CFH})$ were centrifuged (10 $\mathrm{min}$ at 7,000 rpm) and the supernatants were lyophilized and stored in a refrigerator until use. Amino acids (AA), peptides levels (P) in CFH and scavenging effect of CFH on $\alpha$, $\alpha$-diphenyl- $\beta$-picrylhydrazyl (DPPH) free radical were determined spectrophotometrically by OPHA (2), Warburg-Christian (3) and DPPH in vitro (4) methods, respectively.

The highest levels of amino acids and peptides were obtained after hydrolysis for 3 hours with Flavourzyme $1000 \mathrm{~L}: 12.0 \pm 0.5$ and $22.4 \pm 0.5 \%$, respectively. This hydrolisate possessed the most effective abilities as 